Int. J. Electrochem. Sci., 12 (2017) 2207 - 2218

\title{
Microwave Preparation of Catalyst Layer for Enhancing the Oxygen Reduction of Air Cathode in Microbial Fuel Cells
}

\author{
Weifeng Liu, Yonggang Zhou, Shaoan Cheng ${ }^{*}$, Manyan Xu, Fujian Li \\ State Key Laboratory of Clean Energy, Department of Energy Engineering, Zhejiang University, \\ Hangzhou 310027, PR China \\ *E-mail: shaoancheng@zju.edu.cn
}

doi: $10.20964 / 2017.03 .05$

Received: 23 May 2016 / Accepted: 21 June 2016 / Published: 12 February 2017

\begin{abstract}
A novel microwave irradiation method was used to prepare the catalyst layer (CL) of activated carbon air cathodes (ACACs) in microbial fuel cells (MFCs) instead of conventional heating processes. Microwave preparation resulted in a more homogenous distribution of polytetrafluoroethylene (PTFE) in CLs and slightly reduced the hydrophobicity of CLs. These physicochemical characteristics improved the three-phase interfaces (TPIs) for the oxygen reduction reaction (ORR), by increasing the catalytic area of activated carbon and facilitating the diffusion of oxygen gas and $\mathrm{H}^{+} / \mathrm{OH}^{-}$ions. Compared to the conventional ACACs, the charge transfer resistance and the diffusion resistance of the microwave prepared ACACs decreased by $17.6 \% \sim 35.6 \%$ and $18.4 \% \sim 66.2 \%$ respectively. As a result, the maximum power density of MFCs increased by $23.3 \%$ (from $1237 \pm 84 \mathrm{~mW} / \mathrm{m}^{2}$ to $1525 \pm 19$ $\mathrm{mW} / \mathrm{m}^{2}$ ), $15.6 \%$ (from $1370 \pm 36 \mathrm{~mW} / \mathrm{m}^{2}$ to $1584 \pm 9 \mathrm{~mW} / \mathrm{m}^{2}$ ) and $9.2 \%$ (from $1296 \pm 17 \mathrm{~mW} / \mathrm{m}^{2}$ to $1415 \pm 81 \mathrm{~mW} / \mathrm{m}^{2}$ ) respectively at activated carbon/PTFE mass ratios of 4,6 and 8 . This novel preparation method has a promising future as an application in MFCs.
\end{abstract}

Keywords: microbial fuel cell; air cathode; catalyst layer; microwave; power generation

\section{$\underline{\text { FULL TEXT }}$}

(C) 2017 The Authors. Published by ESG (www.electrochemsci.org). This article is an open access article distributed under the terms and conditions of the Creative Commons Attribution license (http://creativecommons.org/licenses/by/4.0/). 